\title{
THE EYE - A NEGLECTED ORGAN IN ENVIRONMENTAL AND OCCUPATIONAL MEDICINE: AN OVERVIEW OF KNOWN ENVIRONMENTAL AND OCCUPATIONAL NON-TRAUMATIC EFFECTS ON THE EYES
}

\author{
Elena ROZANOVA ${ }^{1}$, Peter HEILIG ${ }^{2}$, and Jasminka GODNIĆ-CVAR ${ }^{3}$ \\ Eye Clinic ${ }^{l}$, Department of Ophthalmology, Medical University of Vienna ${ }^{2}$, Department of Occupational Medicine, \\ Clinic of Internal Medicine II, Medical University of Vienna ${ }^{3}$, Vienna, Austria
}

Received in February 2008

Accepted in April 2009

\begin{abstract}
The objective of this study was to give an overview of the known literature data on the influence of environmental and occupational factors on the eye. Sixty-six articles were selected by searching Medline and PubMed databases using the following key words in different combinations: occupational and environmental factors, dry eye syndrome, cataract, retinal vascular changes.

Most of the studies dealt with conditions on the eye surface and used eye discomfort syndrome and dry eye syndrome to outline the effects of air pollutants. Some reported increased frequency of lens opacities due to indoor fuel exposure, in particular biofuel, and negative effects of styrene exposure on colour vision. Investigations of retinal vascular changes and retinopathy after chronic exposure to carbon disulfide $\left(\mathrm{CS}_{2}\right)$ and of retinal and choroidal haemodynamics after exposure to carbon monoxide $(\mathrm{CO})$ found that $\mathrm{CS}_{2}$ caused an increase in retinal venous diameters and $\mathrm{CO}$ caused an increase in arterial and venous diameters, retinal blood flow velocity, and fundus pulsation amplitude. This article also discusses the influence of light exposure on retinal damage. It shows that very little information is available about the influence of environmental and occupational factors on the eye, and retina and retinal vessels in particular.
\end{abstract}

KEY WORDS: cataract, dry eye syndrome, occupational and environmental factors, retinal vascular changes

We substantially rely on our eyes in everyday life, yet this organ has been neglected in occupational medicine. Little effort has been put into the investigation of eye conditions during the working life. An increase of dry kerato-conjunctivits (kerato-conjunctivitis sicca), cataract, and age-related macular degeneration has been observed in the general population. The question is how occupational factors accelerate the natural ageing processes of the eye, and whether specific occupational hazards, in concentrations below the accepted threshold values, induce acute and chronic eye damage or disease. Furthermore, the question is whether we can prevent eye diseases of the advanced age by introducing preventive measures at work and at home.

Air pollution has become ubiquitous. Occupational and environmental air pollution overlap. Both are involved in different health conditions. Numerous 
epidemiological studies have demonstrated short-term associations between high levels of air pollution and increased acute mortality and morbidity (1-5).

There is consistent evidence that increased levels of five major outdoor-air pollutants, that is, particles of less than $10 \mu \mathrm{m}$ in aerodynamic diameter $\left(\mathrm{PM}_{10}\right)$, ozone $\left(\mathrm{O}_{3}\right)$, carbon monoxide $(\mathrm{CO})$, sulphur dioxide $\left(\mathrm{SO}_{2}\right)$, nitrogen monoxide $(\mathrm{NO})$, and nitrogen dioxide $\left(\mathrm{NO}_{2}\right)$ are released into the atmosphere, cross long distances, and induce adverse effects on living nature. They are associated with increased mortality and morbidity in developed and developing countries (6). Nitrogen monoxide and nitrogen dioxide are primary pollutants, which undergo various complex atmospheric reactions to generate secondary pollutants such as ozone, which is known to cause severe adverse effects on human health. In addition to heating, combustion engines are the major source of atmospheric NO (7).

Short-term inhalation of fine airborne particles and ozone, at concentrations that occur in urban environment, has been shown to cause acute conduit artery vasoconstriction (8). Medina et al. and Atkinson et al. have described relations between asthma, bronchitis, cardiovascular conditions (coronary disease) and outdoor pollution rates (9-11). Nitrogen dioxide is known as a deep lung irritant. Schwella (12) found a significant correlation between incidents of asthma and levels of $\mathrm{SO}_{2}, \mathrm{NO}_{2}$, and $\mathrm{PM}_{10}$. Moreover, large epidemiological studies evidenced the association between carbon monoxide, $\mathrm{NO}_{2}$ and coronary events, hospitalisations and mortality $(6,9)$.

Recently, the variety and levels of pollutants in the atmosphere have increased, mainly due to a general rise in combustion exhausts from industry and vehicle traffic. Meteorological conditions such as air temperature, humidity, and atmospheric pressure have also been shown to influence pollution rates.

A survey of literature has shown that in spite of the knowledge on increased pollution rates by the abovementioned four major pollutants and more frequent reports of eye discomfort, little information is available about the effects of air pollution on the eye, particularly on retina and retinal vessels, when compared to the effects of air pollution on pulmonary or cardio-vascular systems (13). Some of the eye effect data come from experimental studies in which air pollutants were used on human volunteers or animals in arbitrary doses or in doses even higher than those ever expected during episodes of air pollution (14, $15)$.

\section{METHODS}

Sixty-six references were selected by searching Medline and PubMed databases using the following key words in different combinations: occupational and environmental factors, dry eye syndrome, cataract, and retinal vascular changes.

\section{EYE SURFACE}

Most of the studies investigating the direct effect of air pollution on the eye have focused on the conditions of the eye surface and used eye irritation as the criterion for the effects of air pollutants (15-41). Manifestations range from minimal or no symptoms to chronic discomfort and eye irritation $(15,17)$, reduction of visibility, and increased light sensitivity (18). The most common eye condition due to air pollution described in literature is the dry eye syndrome (DES). The National Eye Institute/Industry Workshop on Clinical Trials in Dry Eyes (19) defined dry eye as "a disorder of the tear film due to tear deficiency or excessive tear evaporation, which causes damage to the inter-palpebral ocular surface and is associated with symptoms of ocular discomfort".

DES comprises a series of 'minor' subjective symptoms in patients with no relevant clinical signs that would suggest eye disease. Both epidemiological studies and controlled human exposure clinical studies have shown cause-effect relationships between eye discomfort and various outdoor air pollutants as well as indoor irritants which are known to cause the sick building syndrome (SBS). Eye surface inflammation is considered a symptom of pollution-induced DES, without allergy.

Versura et al. (20) conducted a clinical study in 100 patients complaining of DES in the winter and summer using the Schirmer's test I, ferning test, breakup time (BUT), and conjunctival cytology (scraping and imprint). Data were related to sex, age, and air pollution indexes, recorded in the patients' residence areas. The authors demonstrated that eye surface cytology and the analysis of tear film changes provided significant information in patients without evident clinical signs of an eye disease. DES symptoms were found to be more frequent in women than in men (ratio about 2:1) over 51 years of age. The authors concluded that DES was significantly associated with eye surface inflammation, as detected by cytological 
methods, and that eye surface subclinical inflammation and eye dryness were related to high concentrations of atmospheric polluters in both sexes. Specifically affected are contact lens wearers, in whom the effect of air pollution seems to be more prominent (21).

DES, in general, is the most frequent disorder in ophthalmological practice (22). The prevalence of dry eyes varies from $10.8 \%$ to $57.1 \%$ (23-25) depending on the study. Much of this disparity is owed to poor standardisation of patient selection for the study, nonstandardised dry eye questionnaires, lack of objective tests, and dry eye diagnostic criteria. What is believed to cause DES is the abnormality of the pre-ocular tear film, a three-layered structure consisting (from posterior to anterior) of the mucous, aqueous, and the lipid layer. Various risk factors accounting for DES in literature include air pollution, cigarette smoking, low humidity, high temperature, sunlight exposure, and drugs (26-27).

Eye discomfort may be caused by changes in the $\mathrm{pH}$ of the lacrimal film. Andres et al. (28) investigated the influence of air pollution, specifically sulphur dioxide $\left(\mathrm{SO}_{2}\right)$, on tear $\mathrm{pH}$ in a random sample of 100 subjects, divided in three groups according to the stability of their precorneal tear film (PTF) (normal eyes, borderline, and dry eyes). The average $\mathrm{pH}$ value was 7.52. The $\mathrm{pH}$ for borderline and dry eyes was higher than for normal eyes. Authors found that air pollution affected the lacrimal $\mathrm{pH}$, which decreased when the atmospheric $\mathrm{SO}_{2}$ increased.

Gupta et al. (26) described the effects of air pollution on the eyes of persons residing in New Delhi. Tear film abnormalities were present in a large number of people staying within the city, in comparison to people living outside this area, who apparently had normal eyes. The authors suggested that long-term exposure to air pollution could have led to tear film abnormalities. In a study of Sahai and Malik (29) dry eye prevalence increased progressively with age, and the age group (31 to 40) years showed a relative peak. The authors suggested that this peak reflected environmental exposure to which this age group, being the most active occupationally, was exceptionally prone. This phenomenon may be more common in tropical countries where sunlight and wind exposure is substantial. Excessive exposure to wind, sunlight, high temperature, and drugs were significantly related to dry eyes. Most studies report a higher prevalence of dry eye in women than men. Menopause causes oestrogen deficiency and a consequent change in the local hormonal milieu of the lacrimal gland. It is thought to decrease tear production and contribute to the incidence of dry eyes in women. Smoking predisposes the eye to tear film instability by its direct irritant action on the eyes and represents a modifiable risk factor in developing dry eyes. A drug may also disrupt one or more components of the tear film, causing it to become unstable. It is assumed that persons with refractive errors have an increased tendency to rub their eyes. Apart from introducing infectious materials, sebum and sweat, rubbing can introduce foreign substances that lead to tear film instability. It was also demonstrated that dry eye was more prevalent in hypermetropes than in myopes, and was the least prevalent in emmetropes (27). It is also essential to realise that dry eye prevalence is usually higher in contact lens wearers. Bourcier et al. (30) investigated the association between the number of ophthalmologic emergencies, urban air pollution, and climatic conditions in Paris to determine the possibility of creating a surveillance system capable of monitoring trends in the relation between air pollution and ophthalmologic emergencies. Five major urban air pollutants nitrogen oxide, nitrogen dioxide, carbon monoxide, ozone, and sulphur dioxide particles with a median aerodynamic diameter of $<10$ $\mu \mathrm{m}$ were provided by the Paris air pollution network AIRPARIF. Meteorological data for the Paris area were provided by the national weather service, Meteo-France, and included daily minimum and maximum temperature, daily minimum and maximum humidity, mean daily atmospheric pressure, and wind speed. A total of 30,883 patients were examined during 1999, and 3042 diagnoses were recorded in the randomisation process. Among these, 41.8 were categorised as conjunctivitis and related eye surface problems. The relationship between conjunctivitis and related eye surface problems on one hand and air pollution, and meteorological parameters on the other was strong. The oxidative environmental pollutant $\mathrm{NO}_{2}$, high temperature, and wind speed were associated with conjunctivitis and other eye surface diseases. This study suggested that high levels of air pollution in Paris were associated with short-term increases in the number of people visiting ophthalmologic emergency departments. Therefore, the authors suggested that their results indicated a strong relationship between air $\mathrm{NO}$ and/or $\mathrm{NO}_{2}$ and conjunctivitis. Acidification of tears in an atmosphere with a high oxidant power $\left(\mathrm{NO}, \mathrm{NO}_{2}, \mathrm{SO}_{2}\right)$ could thus exert irritanteffect on the eye surface. Furthermore, the authors found that atmospheric pressure, low humidity, 
and high wind speed could have direct mechanical or biological effects on the eye surface and could thus increase the incidence of eye surface complaints. The authors hypothesised that the ophthalmic effects of air pollutants and allergenic pollens could be enhanced by hot weather. Other parameters such as low humidity, and wind speed may directly affect tear film stability. Occupational environment may be an additional burden to the eyes. Eye irritation is one of the most frequently reported symptoms in relation to working in office-like environments. Based on database searches, it was concluded that changes in PTF lead to eye complaints that may be caused by thermal factors (low relative humidity, high room temperature), demanding tasks (concentration decreases blinking and widens the exposed ocular surface area), and individual characteristics (tear film properties, blinking anomalies, gland dysfunction, use of contact lenses, eye make-up, and certain medications) (31). These factors and conditions progressively increase water evaporation and accelerate the thinning of PTF, which causes dryness and dry spot formation on the cornea, possibly followed by corneal and conjunctival epithelial alterations and eye complaints. Other possible causes of eye complaints are certain irritating chemical compounds, in addition to oxidation mixtures formed in reactions between ozone and unsaturated organic compounds (alkenes). If airborne particles alone destabilise the tear film and cause eye irritation, their content of surface-active compounds must be high. The effect may be exacerbated by relative low humidity.

Current considerations have failed to external physical factors that could have a large influence on particle deposition velocity onto the eye surface. Based on previously published models, Schneider and Bohgard (32) described the influence of turbulence, gravitational settling, electrical fields, and thermophoresis on deposition velocity. They used a probabilistic approach to determine percentile ranges in deposition velocity when the magnitude of these parameters varied within typical ranges. These calculations suggest that differences in external factors other than particle size may cause differences in deposition velocity onto the ocular surface.

Office workers frequently report eye problems, including dryness, burning, feeling of sand in the eyes, or increased lacrimation. Brasche et al. (33) described factors affecting self-reported eye symptoms and objectively determined tear film characteristics using data from 814 office workers. Multiple logistic regression analysis revealed a significantly increased incidence of eye symptoms in women, contact lens wearers, and in patients with chronic diseases. A reduced BUT depended on the history of eye disease and female sex. Age under 40 years, high relative humidity, and formaldehyde exposure exceeding the $90^{\text {th }}$ percentile were protective regarding BUT. High particle load, high endotoxin concentration, and female sex turned out to significantly increase the risk be of the thin lipid layer (an indication of dry eyes). The authors, therefore, concluded that objective clinical methods were to be applied for field monitoring to complement less objective questionnaires. Selfreported eye symptoms associated with indoor environment should be validated by objective medical examinations such as semi-quantitative estimation of the superficial lipid layer, measurement of the breakup time, or the assessment of conjunctival epithelial damage. Individual physical and psychological factors such as acute illness or low job satisfaction should be additionally taken into account. Indoor and outdoor air pollution should be controlled, including, as a minimum requirement, measurements of particles, $\mathrm{NO}_{2}$, relative humidity, and endotoxin levels to detect environmental influences on eye symptoms.

In several studies, changes in eye blink frequency were used as an indicator of sensory irritation due to trigeminal stimulation by exposure to indoor pollutants. In a study of Kleno and Wolkoff (34) mean blink frequency increased significantly in subjects exposed to lower levels of limonene oxidation products (LOPs) and nitrate radicals $\left(\mathrm{NO}_{3}\right)$, compared to controls. Neither the residual reactants nor clean air changed the blink frequency significantly. The authors concluded that changes in blink frequency were a promising measure of trigeminal stimulation from exposure to eye irritants. Gaseous products of limonene and ozone may cause eye irritation indoors. In addition, Kiesswetter et al. (35) showed a strong dose-response relationship between airborne solvent concentrations and blink rates. The authors showed that during peak exposures to $40 \mathrm{mg} \mathrm{kg}^{-1}$ 2-ethylhexanol, blink rate increased threefold. In four hours exposure, blink rate increased significantly, showing no adaptation. These results indicate that the irritative potential of 2-ethylhexanol is higher than generally expected. The authors suggested that electromyographic eye blink recordings were an objective and therefore appropriate method for the examination of acute sensory irritations. 
Kjaergaard et al. (36) performed a population study of eye trigeminal sensitivity, tear film stability, and conjunctival epithelium damage in a random sample of 182 non-allergic, non-smoking citizens of the Aarhus County, Denmark. They analysed the distribution of eye sensitivity to $\mathrm{CO}_{2}$-induced irritation (COI), tear film stability (BUT), and epithelium damage (ED), and the relation of these parameters with age and sex. COI was normally distributed across the population strata, and the total score for ED deviated marginally. With age BUT and COI decreased. Sex difference was observed for ED, which was more frequent in women. There was no relationship between the outcomes of these three evaluation methods. Reduced BUT was seen in subjects reporting high levels of exposure to dust, electrostatic fields, and dry air, while ED increased with high temperatures.

Eye blinking is essential for the maintenance of the eye tear film. Therefore, eye blink rate may be used to study pre-corneal tear film integrity, which is influenced by eye blinking efficiency (37). Sjogaard et al. (38) used the electro-oculogram (EOG) as a measure of eye blink rate during computer work. EOG was evaluated against video recordings as an easy-to-use measure of eye blinking and was therefore considered a potential method for quantifying eye blinks during prolonged working periods.

Recent studies contributed to considerations about the effects of indoor and outdoor air pollution on human eye surface. Leonardi and Lanier (39) described the so called "urban eye allergy syndrome". In a significant number of patients who visited outpatient clinics, conjuctivitis could not be categorised as either allergic, infectious, or "dry eye". Patients affected by this pseudo-allergic form of vasomotor or idiopathic conjunctivitis usually live in urban polluted areas and may be affected by a new clinical entity. Both allergens and pollutants can directly initiate specific and nonspecific mucosal inflammation through several common pathways. Novaes et al. (40) found a positive and significant association between exposure to air pollution and goblet-cell hyperplasia in human conjunctiva, using a combination of simple measurements of exposure to air pollution and impression cytology, which was found to be an effective non-invasive approach for characterising human response to ambient levels of air pollution. Bakke et al. (41) presented the association between airway symptoms, complaints of reduced environmental perceptions, atopy, and biomarkers including tear film stability (BUT), nasal patency, and nasal lavage (NAL). Personal predictors (sex, age, smoking, and infections) for these biomarkers as well as associations between the biomarkers were also assessed. BUT was measured using a non-invasive method (NIBUT) and self-reported impression (SBUT). In NAL, the following parameters were analysed: eosinophilic cationic protein (ECP), myeloperoxidase (MPO), lysozyme, and albumin. Total serum IgE and specific IgE were measured using the Phadiatop test. Data on subjective symptoms, environmental perception and demographic data were collected using a questionnaire. The authors concluded that BUT and NAL-lysozyme were associated with ocular, nasal, and laryngeal symptoms, and reduced indoor environmental perception. Asthma and hay fever were predictors for the symptoms and perceived air quality, respectively. Phadiatop test findings, total IgE, familial allergy, and eczema were not associated with symptoms or environmental perception. Age, sex and Phadiatop test findings were the main predictors for ocular and nasal biomarkers.

\section{COLOUR VISION}

Colour vision is known to deteriorate as a consequence of neurotoxic agents (solvents) at work. This deterioration correlates with exposure duration and intensity. Research on this topic was comprehensively covered by Iregren et al. (42) in their review of literature published until December 2000 on colour vision and occupational chemical exposure. Briefly, several types of tests of colour vision are available, including pseudo-isochromatic plates (standard pseudoisochromatic plates, Ishihara plates, American Optical plates, and the City University tritan) and colour arrangement tests [Farnsworth D15, Farnsworth-Munsell 100-hue test (FM 100), and Lanthony D15 de-saturated panel]. Occupational exposure to styrene, toluene, perchloroethylene, carbon disulphide, and $n$-hexane were studied mainly using the Lanthony D15 and FM 100 tests. It was found that long-term exposure even to low levels of styrene and carbon disulphide could adversely affect colour vision. Long-term low-level exposure to carbon disulphide was found to cause acquired colour vision deficiency (43). Deteriorated colour vision caused by $n$-hexane and perchloroethylene was associated with even a small increase in the exposure level. In addition, Iregren et al. (44) studied acute occupational styrene exposure and colour vision in 108 workers (21 to 65) 
years at Swedish reinforcement plastic plants. Colour vision was tested using the Lanthony D15 desaturated panel binocular test without prior training (ample light $14001 \mathrm{x}$ ). This study indicated that acute styrene exposure, even at levels below the current Swedish OEL of $20 \mathrm{mg} \mathrm{m}^{-3}$, adversely affected colour vision.

\section{CATARACT}

Age-related cataract is another very important eye condition, which is probably also influenced by outdoor and indoor air pollution. According to the World Health Organization (WHO), more than one million people become blind worldwide each year, and cataract accounts for more than $50 \%$ of these cases (45). The prevalence of cataract is higher in developing countries, and it affects more women than men (45-48). A broad range of factors may influence cataract formation. These include age, current cigarette smoking, exposure to UV radiation (sunlight), ionising radiation, microwave radiation, high temperatures, and metabolic conditions such as malnutrition, diabetes, and chronic severe diarrhoea. Exposure to indoor air pollution generated by combustion of traditional biomass fuels (wood, charcoal, animal dung, and crop wastes) and of coal is a significant environmental hazard, predominantly affecting populations of developing countries (49-51). There is consistent evidence that exposure to biomass smoke increases the risk of a range of common diseases in children and adults $(46,51)$. Recently, several epidemiological studies have provided evidence of an association between cooking with solid fuels and cataract formation or blindness (52-54). Wood combustion was found to be an important factor in the aetiology of age-related cataract. Typical occupational cataracts were thoroughly described in ore-melting oven (steel) workers and workers exposed to organic solvents (TNT) and to ionising radiation (rarely seen nowadays due to efficient protection).

\section{RETINA AND RETINAL VESSELS}

Although it was established that fine particulate and ozone air pollution are associated with increased cardiovascular events and that short-term inhalation of fine airborne particles and ozone at concentrations that occur in the urban environment can cause acute conduit artery vasoconstriction, there is hardly any evidence of the effect of air pollution on the retinal and choroidal vessels.

Remky et al. (55) measured retinal vessel diameters using non-mydriatic fundus photography in an medical and ergonomic field study of occupational exposure to carbon disulphide $\left(\mathrm{CS}_{2}\right)$. They found that chronic exposure to carbon disulphide may lead to retinal vascular changes and retinopathy. While venous diameters were significantly larger in 166 subjects exposed to $\mathrm{CS}_{2}$ than in 140 non-exposed subjects, there was no significant effect of $\mathrm{CS}_{2}$ exposure on arterial diameters. However, both the arterial and venous diameters negatively correlated with age. Remky et al. concluded that occupational $\mathrm{CS}_{2}$ exposure lead to significant changes in retinal venous diameters and suggested that non-mydriatic fundus photography for diameter measurements was a useful tool in toxicological studies. Recently, Resch et al. (56) investigated the effect of inhaled CO on retinal and choroidal blood flow. The hypothesis was that carbon monoxide (CO) acts as an important vascular paracrine factor and plays a role in blood flow regulation in several tissues. This randomized, double-blind, placebo-controlled study included fifteen healthy male volunteers who inhaled either $500 \mathrm{mg} \mathrm{kg}^{-1}$ of $\mathrm{CO}$ or placebo (synthetic air without $\mathrm{CO}$ ) for $60 \mathrm{~min}$. Ocular hemodynamics was measured at baseline and at $30 \mathrm{~min}$ and $60 \mathrm{~min}$ of inhalation. These authors found that $\mathrm{CO}$ inhalation caused the widening of retinal arteries and veins independent of the significant increase of carboxyhaemoglobin. Retinal blood flow, subfoveal choroidal blood flow, and fundus pulsation amplitude increased significantly in response to $\mathrm{CO}$ inhalation. It remains unclear whether this increase is caused by tissue hypoxia or another mechanism. On the other hand, no changes in the retinal microcirculation were found in a series of fundoscopy studies which investigated the effects of sustained low-level elevations of carbon dioxide on cerebral blood flow and on the auto-regulation of intracerebral arteries in humans (57). Cerebral blood flow velocity (CBFv) was measured by insonating the middle cerebral arteries of four subjects using a $2 \mathrm{MHz}$ transcranial Doppler. It was elevated significantly during the first 1 to 3 days post exposure, after which $\mathrm{CBFv}$ progressively readjusted to preexposure levels. Sliwka et al. (57) hypothesised that time-dependent changes in $\mathrm{CO}_{2}$ vascular reactivity might be caused either by retention of bicarbonates in brain extracellular fluid or by progressive increases in ventilation, or both. 
Recent studies have suggested that exposure to exhaust particles and ambient air pollution increases carotid intima-media thickness and reduces ocular blood flow velocity. Memişoğullari et al. (58) assessed the relationship between serum homocysteine, a potential parameter for atherosclerosis, and ocular blood flow velocity and resistivity index in 22 highway toll collectors and 24 control subjects using colour Doppler ultrasonography. The authors showed significant correlations between serum homocysteine level and ophthalmic artery resistivity index in both highway toll collectors $(\mathrm{p}<0.001)$ and controls $(\mathrm{p}<0.005)$ and suggested that exposure to exhaust particles might increase serum homocysteine level, which in turn could lead to reduced ocular blood flow and increased resistivity index.

Environmental tobacco smoke (ETS) has been proposed to be a risk factor for age-related macular degeneration, Graves ophthalmology, glaucoma, uveitis, refractive errors, strabismus, tobacco-alcohol amblyopia, non-arteritic ischaemic optic neuropathy, Leber optic neuropathy, and diabetic retinopathy (59). To better understand the cellular and molecular basis of the epidemiologic association between cigarette smoke and age-related macular degeneration (AMD), Sharma et al. (60) examined the effects of benzo(e)pyrene $(\mathrm{B}(\mathrm{e}) \mathrm{P})$, a toxic element in cigarette smoke, on human retinal pigment epithelial cells (ARPE-19). These results show that $\mathrm{B}(\mathrm{e}) \mathrm{P}$ is toxic for human retinal pigment epithelial cells in vitro. It causes cell death and induces apoptosis by the involvement of multiple caspase pathways. Klein et al. (61) has also suggested that smoking is related to the long-term incidence and progression of AMD.

Many conditions, in which free radicals are generated, such as sunlight, cigarette smoke, air pollution, infection, and metabolic processes can cause damage to the layers of retinal vessels and induce neovascularisation. Diabetic retinopathy and wet AMD are together responsible for the majority of progressive blindness in the world today. In both of these diseases, the induction of new aggressive blood vessel growth consecutively leading to oedema, macular thickening, bleeding in the eye, and eventual scarring of the retinal tissues can result in the rapid loss of vision.

\section{EXPOSURE TO LIGHT AND RETINAL DAMAGE}

A number of clinical and experimental studies have investigated the association between exposure to light and retinal damage. We can only briefly focus on this issue in this overview. It is well established that ultraviolet (UV) and visible radiation has the potential to damage the retina and pigment epithelium (62). The human retina is exposed only to the "visible component" of the electromagnetic spectrum from (400 to 760) nm and to some shortwavelength infrared (IR) radiation. This part of the electromagnetic spectrum may result in chronic or acute tissue damage when it is absorbed by any one of a number of photosensitisers or chromophores such as visual pigments, melanin, melanopsin, lipofuscin, flavins, and flavoproteins. Evidence collected since the 1970s suggests that light may damage the retina in a number of ways involving different chromophores and cellular events (63). Short-intense exposure (from $100 \mathrm{~ms}$ to $10 \mathrm{~s}$ ) may result in thermal damage when incident energy is absorbed by a tissue and there is a significant rise in local temperature. The action spectra for this type of damage depends on the absorption characteristics of the chromophore, but typically peaks in the blue/green, green and red regions of the visible spectrum (64). Although such exposures are used therapeutically, to produce retinal photocoagulation, they are not encountered in the natural world.

Longer exposure (typically $10 \mathrm{~s}$ and longer) to far less intense light sources may cause retinal damage by a photochemical mechanism. It seems to be the same mechanism that is most likely to be of relevance to the development of AMD.

Photochemical reactions take place in normal ambient conditions and involve a reaction between energetic photons and an absorbing molecule. In the presence of oxygen, this reaction leads, via a number of intermediary steps, to the production of reactive oxygen species (ROS), including singlet oxygen, superoxide, hydrogen peroxide and hydroxyl radicals. These ROS are highly toxic and can cause lipid peroxidation, protein oxidation, and mutagenesis. Although ROS production is a natural by-product of cellular respiration, it is believed to have a major role in ageing (65) and contributes to the development of AMD. In a comprehensive review, Margrain et al. (66) evaluated the long-held belief that blue light exposure has a role in the pathogenesis of AMD. The precise chromophore that may be involved in the pathogenesis of AMD is unclear, but the age pigment lipofuscin is a likely candidate. Its aerobic photoreactivity and adverse effects on antioxidant activity combined with its gradual accumulation over time suggests that its in vivo phototoxicity increases with age despite changes 
in the absorption characteristics of the crystalline lens. Evidence from animal studies confirms blue light's damaging potential, but the results are not directly applicable to macular degeneration in humans. Studies of human macular pigment density and the risk of AMD progression following cataract surgery lend further weight to the hypothesis that blue light exposure has a role in the pathogenesis of AMD. The role in retinal photodamage of flavins and porphyrins, present as prosthetic groups of several important enzymes, is still poorly understood. Lipofuscin, which accumulates during ageing in the retinal pigment epithelium (RPE), is a potent photosensitiser, which photogenerates singlet oxygen, superoxide anion, hydrogen, and lipid peroxide. However, it is still unknown which molecular constituent of lipofuscin is responsible for its photoreactivity. Melanin has been rejected as a potential candidate responsible for photochemical damage to the retina based on observations of the similarity of endpoints in photodamage in albino and pigmented animals. However, photoprotective effects may counterbalance the photodamaging effects of melanin in pigmented animals, as melanin absorbs a significant fraction of incident photons. Macular pigment is most likely to play a protective role as a blue light filter and possibly as an antioxidant, but more experimental evidence is needed to support this hypothesis (64). Authors suggested that a better understanding of the photo-induced processes in the retina may help to predict what levels of illumination are safe for the normal retina and to specify the conditions under which even ambient solar radiation may impose a risk of retinal photodamage.

\section{CONCLUSION}

Occupational hygiene measures, such as decreasing the level of particles and gaseous air pollutants at the workplace as well as optimising illumination and humidity at the workplace are the major steps in the prevention of eye disease. Occupational biomonitoring in terms of yearly eye check-ups, including visual acuity, Schirmer's test, BUT, and ophthalmoscopy for workers exposed to adverse microclimatic conditions or high eye strain should be the second level of intervention in preventing chronic eye damage.

Prospective longitudinal research in environmental and occupational medicine is needed in order to improve the understanding and diagnostic approach to ocular damage caused by environmental and occupational factors. These studies will help to understand the long-term environmental and occupational effects on the eye, which superimpose on the ageing processes in the ever ageing working population as a consequence of the evolving demographic shift. Insights into the mechanisms of these events may help us develop preventive measures during the working life, not only in preventing occupational diseases, but also in using occupational surveillance to counteract ocular disability of the advanced age.

\section{REFERENCES}

1. Katsouyanni K, Touloumi G, Samoli E, Gryparis A, Le Tertre A, Monopolis Y, Rossi G, Zmirou D, Ballester F, Boumghar A, Anderson HR, Wojtyniak B, Paldy A, Braunstein R, Pekkanen J, Schindler C, Schwartz J. Confounding and effect modification in the short-term effects of ambient particles on total mortality: results from 29 European cities within the APHEA2 project. Epidemiology 2001;12:521-31.

2. Lippmann M, Ito K, Nádas A, Burnett RT. Association of particulate matter components with daily mortality and morbidity in urban populations. Res Rep Health Eff Inst 2000;95:5-72, discussion 73-82.

3. Petroeschevsky A, Simpson RW, Thalib L, Rutherford S Associations between outdoor air pollution and hospital admissions in Brisbane, Australia. Arch Environ Health 2001;56:37-52

4. Thiele JJ, Podda M, Packer L Tropospheric ozone: an emerging environmental stress to skin. Biol Chem 1997;378:1299-1305.

5. Thielebeule U, Pelech L Epidemiological studies regarding the effects of air pollution. J Hyg Epidemiol Microbiol Immunol 1985;29:353-62.

6. Samet JM, Dominici F, Curriero FC, Coursac I, Zeger SL Fine particulate air pollution and mortality in 20 U.S. cities, 1987-1994. N Engl J Med 2000;343:1742-9.

7. Lal S, Patil RS. Monitoring of atmospheric behaviour of NOx from vehicular traffic. Environ Monit Assess 2001;68:3750 .

8. Brook RD, Brook JR, Urch B, Vincent R, Rajagopalan S, Silverman F. Inhalation of fine particulate air pollution and ozone causes acute arterial vasoconstriction in healthy adults. Circulation 2002;105:1534-6.

9. Medina S, Le Tertre A, Quenel P, Le Moullec Y, Lameloise P, Guzzo JC, Festy B, Ferry R, Dab W. Air pollution and doctors' house calls: results from the ERPURS system for monitoring the effects of air pollution on public health in Greater Paris, France, 1991-1995. Environ Res 1997;75:73-84.

10. Atkinson RW, Anderson HR, Strachan DP, Bland JM, Bremner SA, Ponce de Leon A. Short-term associations between outdoor air pollution and visits to accident and emergency departments in London for respiratory complaints. Eur Respir J 1999;13:257-65.

11. Atkinson RW, Anderson HR, Sunyer J, Ayres J, Baccini M, Vonk JM, Boumghar A, Forastiere F, Forsberg B, 
Touloumi G, Schwartz J, Katsouyanni K. Acute effects of particulate air pollution on respiratory admissions: results from APHEA 2 project. Air Pollution and Health: a European Approach. Am J Respir Crit Care Med 2001;164:1860-6.

12. Schwela D. Air pollution and health in urban areas. Rev Environ Health 2000;15:13-42.

13. Saxena R, Srivastava S, Trivedi D, Anand E, Joshi S, Gupta SK. Impact of environmental pollution on the eye. Acta Ophthalmol Scand 2003;81:491-4.

14. Anderson RC, Anderson JH. Sensory irritation and multiple chemical sensitivity. Toxicol Ind Health 2003;15:339-45.

15. Waheed MA, Basu PK. The effect of air pollutants on the eye. I. The effect of an organic extract on the conjunctival goblet cells. Can J Ophthalmol 1970;5:226-30.

16. Artridge RA, Stebbings JH Jr, Elsea WR, Winkelstein W Jr. Outbreak of acute eye irritation associated with air pollution. Public Health Rep 1966;81:153-8.

17. Altshuller AP. Eye irritation as an effect of photochemical air pollution. J Air Pollut Control Assoc 1977;27:1125-6.

18. Basu PK. Air pollution and the eye. Surv Ophthalmol 1972;17:78-93.

19. Lemp MA. Report of the National Eye Institute/Industry Workshop on clinical trials in dry eyes. CLAO J 1995;21:22132.

20. Versura P, Profazio V, Cellini M, Torreggiani A, Caramazza R. Eye discomfort and air pollution. Ophthalmologica 1999;213:103-9.

21. Klopfer J. Effects of environmental air pollution on the eye. J Am Optom Assoc 1989;60:773-8.

22. Murube J, Wilson S, Ramos-Esteban J. New horizons in the relief and control of dry eye. Highlights Ophthalmol 2001;29:55-64.

23. Albietz JM. Prevalence of dry eye subtypes in clinical optometry practice. Optom Vis Sci 2000;77:357-63.

24. Hikichi T, Yoshida A, Fukui Y, Hamano T, Ri M, Araki K, Horimoto K, Takamura E, Kitagawa K, Oyama M. Prevalence of dry eye in Japanese eye centers. Graefes Arch Clin Exp Ophthalmol 1995;233:555-8.

25. Versura P, Cellini M, Torreggiani A, Profazio V, Bernabini B, Caramazza R. Dryness symptoms, diagnostic protocol and therapeutic management: A report on 1,200 patients. Ophthalmic Res 2001;33:221-7.

26. Gupta SK, Gupta V, Joshi S, Tandon R. Subclinically dry eyes in urban Delhi: An impact of air pollution? Ophthalmologica 2002;216:368-71.

27. Moss SE, Klein R, Klein BE. Prevalence of and risk factors for dry eye syndrome. Arch Ophthalmol 2000;118:1264-8.

28. Andrés S, Garcia ML, Espina M, Valero J, Valls O. Tear $\mathrm{pH}$, air pollution, and contact lenses. Am J Optom Physiol Opt 1988;65:627-31.

29. Sahai A, Malik P. Dry eye: prevalence and attributable risk factors in a hospital-based population. Indian J Ophthalmol 2005;53:87-91.

30. Bourcier T, Viboud C, Cohen JC, Thomas F, Bury T, Cadiot L, Mestre O, Flahault A, Borderie V, Laroche L. Effects of air pollution and climatic conditions on the frequency of ophthalmological emergency examinations. $\mathrm{Br}$ J Ophthalmol 2003;87:809-11.

31. Wolkoff P, Skov P, Franck C, Petersen LN. Eye irritation and environmental factors in the office environment-hypotheses, causes and a physiological model. Scand J Work Environ Health 2003;29:411-30.
32. Schneider T, Bohgard M. Airborne particle deposition onto the ocular surface. Indoor Air 2005;15:215-19.

33. Brasche S, Bullinger M, Petrovitch A, Mayer E, Gebhardt H, Herzog V, Bischof W. Self-reported eye symptoms and related diagnostic findings-comparison of risk factor profiles. Indoor Air 2005;15(Suppl 10):56-64.

34. Kleno J, Wolkoff P. Changes in eye blink frequency as a measure of trigeminal stimulation by exposure to limonene oxidation products, isoprene oxidation products and nitrate radicals. Int Arch Occup Environ Health 2004;77:235-43.

35. Kiesswetter E, van Thriel C, Schaeper M, Blaszkewicz M, Seeber A. Eye blinks as indicator for sensory irritation during constant and peak exposures to 2-ethylhexanol. Environ Toxicol Pharmacol 2005;19:531-41.

36. Kjaergaard SK, Hempel-Jorgensen A, Molhave L, Andersson K, Juto JE, Stridh G. Eye trigeminal sensitivity, tear film stability and conjunctival epithelium damage in 182 nonallergic, non-smoking Danes. Indoor Air 2004;14:200-7.

37. Wolkoff P, Nojgaard JK, Troiano P, Piccoli B. Eye complaints in the office environment: precorneal tear film integrity influenced by eye blinking efficiency. Occup Environ Med 2005;62:4-12.

38. Sjøgaard G, Skotte J, Nøjgaard JK, Jørgensen LV, Nielsen PK, Hansen EA, Hye-Knudsen CT, Søgaard K, Wolkoff P. Electro-oculogram as measure of eye blink rate during computer work. FASEB J 2005;19:A1280.

39. Leonardi A, Lanier B. Urban eye allergy syndrome: a new clinical entry? Curr Med Res Opin 2008;24:2295-2302.

40. Novaes P, do Nascimento Saldiva PH, Kara-José N, Macchione M, Matsuda M, Racca L, Berra A. Ambient levels of air pollution induce goblet-cell hyperplasia in human conjunctival epithelium. Environ Health Perspect 2007;115:1753-6.

41. Bakke JV, Wieslander G, Norbäck D, Moen BE. Atopy, symptoms and indoor environmental perceptions, tear film stability, nasal patency and lavage biomarkers in university staff. Int Arch Occup Environ Health 2008;81:861-72.

42. Iregren A, Anderson M, Nylén P. Color vision and occupational chemical exposures: I. An overview of tests and effects. Neurotoxicol 2002;23:719-33.

43. Valic E, Pilger A, Pirsch P, Pospischil E, Waldhör T, Rüdiger HW, Wolf C. Nachweise erworbener Farbsinnstörung bei $\mathrm{CS}_{2}$ exponierten Arbeitern in der Viskoseproduktion [Proof of acquired color vision disturbance in $\mathrm{CS}_{2}$ exposed workers in viscosisproduction, in German]. Arbeitsmed Sozialmed Umweltmed 2001;36:59-63.

44. Iregren A, Johnson AC, Nylén P. Low-level styrene exposure and color vision in Swedish styrene workers. Environ Toxicol Pharmacol 2005;19:511-6.

45. Bruce N, Perez-Padilla R, Alablak R. Indoor air pollution in developing countries: a major environmental and public health challenge. WHO Bulletin 2000;78:1078-92.

46. Mishra V. Effect of indoor air pollution from biomass combustion on prevalence of asthma in the elderly. Environ Health Perspect 2003;111:71-8.

47. Smith K, Samet J, Romieu I, Bruce N. Indoor air pollution in developing countries and acute respiratory infections in children. Thorax 2000;55:518-32.

48. Junk AK, Haskal Z, Worgul BV. Cataract in interventional radiology - an occupational hazard? Invest Ophthalmol Vis Sci 2004;45(Suppl. 1):U178.

49. Sreenivas V, Prabhakar AK, Badrinath SS, Fernandez T, Roy IS, Sharma T, Shah B. A rural population based case-control 
study of senile cataract in India. J Epidemiol 1999;9:32736.

50. Ughade SN, Zodpey SP, Khanolkar VA. Risk factors for cataract: a case control study. Indian J Ophthalmol 1998;46:221-7.

51. Ellegard A. Tears while cooking: an indicator of indoor air pollution and related health effects in developing countries. Environ Res 75:12-22

52. Saha A, Kulkarni PK, Shah A, Patel M, Saiyed HN. Ocular morbility and fuel use: an experience from India. Occup Environ Med 2005;62:66-9.

53. Shalini VK, Luthra M, Srinivas L, Rao SH, Basti S, Reddy $\mathrm{M}$, Balasubramanian D. Oxidative damage to the eye lens caused by cigarette smoke and fuel smoke condensates. Indian J Biochem Biophys 1994;31:261-6.

54. Pokhrel AK, Smith KR, Khalakdina A, Deuja A, Bates MN. Case-control study of indoor cooking smoke exposure and cataract in Nepal and India. Int J Epidemol 2005;34:70910.

55. Remky A, Dressen D, Plange N, Korinth G, Drexler H, Arend O. Retinal vessel diameters determined in an ergomedical field study: Diameter changes associated with the occupational exposure to carbon disulfide. Invest Ophthalmol Vis Sci 2004;45(Suppl. 2):U619.

56. Resch H, Zawinka C, Weigert G, Schmetterer L, Garhöfer G. Inhaled carbon monoxide increases retinal and choroidal blood flow in healthy humans. Invest Ophthalmol Vis Sci 2005;46:4275-80.

57. Sliwka U, Krasney JA, Simon SG, Schmidt P, Noth J. Effects of sustained low-level elevations of carbon dioxide on cerebral blood flow and autoregulation of the intracerebral arteries in humans. Aviat Space Environ Med 1998;69:299-306.

58. Memişoğullari R, Yüksel H, Coskun A, Yüksel HK, Yazgan O, Bilgin C. High serum homocysteine levels correlate with a decrease in the blood flow velocity of the ophthalmic artery in highway toll collectors. Tohoku J Exp Med 2007;212:247-52.

59. Lois N, Abdelkader E, Reglitz K, Garden C, Ayres JG. Environmental tobacco smoke exposure and eye disease. $\mathrm{Br}$ J Ophthalmol 2008;92:1304-10.

60. Sharma A, Neekhra A, Gramajo AL, Patil J, Chwa M, Kuppermann BD, Kenney MC. Effects of Benzo(e)Pyrene, a toxic component of cigarette smoke, on human retinal pigment epithelial cells in vitro. Invest Ophthalmol Vis Sci 2008;49:5111-7.

61. Klein R, Knudtson MD, Cruickshanks KJ, Klein BE. Further observations on the association between smoking and the long-term incidence and progression of age-related macular degeneration: the Beaver Dam Eye Study. Arch Ophthalmol 2008;126:115-21.

62. Noell WK, Walker V, Kang B, Berman S. Retinal damage by light in rats. Invest Ophthalmol 1966;5:450-73.

63. Kremers JJM, Van Noren D. Two classes of light damage of the retina. Lasers Light Ophthalmol 1988;2:41-53.

64. Boulton M, Rozanowska M, Rozanowski B. Retinal photodamage. J Photochem Photobiol B 2001;64:144-61.

65. Barja G. Endogenous oxidative stress: relationship to aging, longevity and caloric restriction. Ageing Res Rev 2002;1:397-411.

66. Margrain TH, Boulton M, Marshall J, Sliney DH. Do blue light filters confer protection against age-related macular degeneration? Prog Retin Eye Res 2004;23:523-31. 
Sažetak

\section{OKO - ZAPOSTAVLJENI ORGAN U MEDICINI RADA: LITERATURNI PREGLED POZNATIH} EFEKATA OKOLIŠNIH I RADNIH ONEČIŠĆENJA NA OKO

Cilj ovog pregleda bio je dobivanje uvida u opseg informacija na području utjecaja okolišnih i radnih faktora na oči. Izabrali smo šezdeset šest radova pretražujući Medline i PubMed baze podataka na ključne riječi u više kombinacija: oko, radna okolina, okoliš, sindrom suhog oka, katarakta, krvožilne promjene mrežnice, oštećenje oka svjetlošću. Većina radova bavi se stanjima površine oka, i upotrebljava "sindrom neudobnoga oka" (engl. eye discomfort syndrome) i sindrom suhog oka (engl. dry eye syndrome) kao pokazatelje utjecaja polutanata. Primijećeno je učestalo zamućenje očne leće kao posljedica izloženosti gorivima u zatvorenim prostorijama, osobito biogorivima te štetan utjecaj ekspozicije stirenu na raspoznavanje boja. Istraživan je utjecaj kronične ekspozicije ugljičnom disulfidu $\left(\mathrm{CS}_{2}\right)$ na promjene krvnih žila retine te promjena prokrvljenosti mrežnice i koroideje kao posljedica ekspozicije ugljičnom monoksidu (CO). Uočeno je da $\mathrm{CS}_{2}$ uzrokuje povećanja promjera retinalnih vena, a $\mathrm{CO}$ uzrokuje povećan promjer i arterija i vena mrežnice. Posljedično se uočava ubrzanje protoka krvi kroz žile mrežnice i pojačanje amplitude pulzacija žila fundusa. Diskutiran je i štetni utjecaj svjetla na mrežnicu. Pregled literature pokazuje da je opseg informacija na području utjecaja okolišnih i radom uvjetovanih čimbenika na oči oskudan, osobito s obzirom na utjecaj ovih faktora na mrežnicu i njezine krvne žile.

KLJUČNE RIJEČI: katarakta, krvožilne promjene mrežnice, okoliš, oštećenje oka svjetlošću, radna okolina, sindrom suhog oka

\section{CORRESPONDING AUTHOR:}

Univ. Prof. Dr. Jasminka Godnić-Cvar

Department of Occupational Medicine, Clinic of

Internal Medicine IV, Medical University of Vienna, Währingergürtel 18-20, 1090 - Vienna, Austria

E-mail: jasminka.godnic-cvar@meduniwien.ac.at 